\title{
Scythris clavella (Zeller, 1855) in Italy (Lepidoptera, Gelechioidea, Scythrididae)
}

\author{
M. Pinzari \\ Department of Biology, University Tor Vergata of Rome, Italy
}

\begin{abstract}
During an extensive collection of Lepidoptera in Reatini Mountains (Central Apennines, Italy) a male of Scythris clavella (Zeller, 1855) was collected. This species is distributed in Central and Southern Europe and eastwards to Bulgaria, Greece, Southern Ural Mountains, Altai Mountains and Central Asia (Kazakhstan, Kirgisia). It was cited for Italy; however, accurate data of its presence are not present in literature. Our data support the conclusion that it is the first record for Peninsular Italy.
\end{abstract}

\section{Introduction}

The family Scythrididae is part of the superfamily Gelechioidea and includes small or medium-sized moths, which are usually rather difficult to separate from each other owing to the small differences in their external appearance. In the past many misidentifications were made but when examination of the genitalia became a standard procedure the reliability of the determination increased considerably. It has a worldwide distribution, and scythridids may be found even in isolated islands, where they often show special features, which differ from the

Correspondence: Manuela Pinzari, Department of Biology, University Tor Vergata of Rome, via della Ricerca Scientifica 1, 00133 Rome, Italy.

Tel.: +39.06.72595950 - Fax: +39.06 .72595965 .

E-mail: manuela.pinzari@uniroma2.it

Key words: Scythris clavella; Italian fauna; Lepidoptera.

Acknowledgements: I wish to thank Professor Peter Passerin d'Entreves (University of Turin, Italy) for confirming the determination and his valuable suggestions and the final reading of the manuscript; Prof. Mario Pinzari that offers its collection for my study.

Received for publication: 5 February 2016.

Revision received: 12 February 2016.

Accepted for publication: 8 March 2016.

CCopyright M. Pinzari, 2016

Licensee PAGEPress, Italy

Journal of Entomological and Acarological Research 2016; $48: 5798$

doi:10.4081/jear.2016.5798

This article is distributed under the terms of the Creative Commons Attribution Noncommercial License (by-nc 4.0) which permits any noncommercial use, distribution, and reproduction in any medium, provided the original author(s) and source are credited. rest of the family. In the Palaearctic area more than 300 species are known and in the Mediterranean area many species are present with high numbers especially in Spain and Turkey (Bengtsson, 1997).

At present, the Italian scythridid fauna and its distribution is still poorly known. In fact, few regions were detected with dedicated sampling and several areas are still completely unknown. For nearly twenty years an extensive work was carried out for a revision of the Palaearctic scythridid species revealing some synonymies due to the great intraspecific variability and interspecific uniformity within the family (Passerin d'Entreves, 1995).

The genus Scythris is the most extensive of thirteen genera of the family Scythrididae. In Italy, it is represented by sixty species (Passerin d'Entreves, 1995). Among these, Scythris clavella is not a common species in Italy and accurate data of its presence are unknown in literature. In fact, $S$. clavella has been reported from Italy without specifying localities (Bengtsson, 1984; 1997); it is mentioned as doubtful in the checklist of Italian Fauna for the north of the peninsula (Passerin d'Entreves, 1995), while the species is cited generically as present in Italy on the website of Fauna Europaea (Karsholt \& Nieukerken, 2013).

In the past, $S$. clavella has been the subject of investigations when the congeneric species Scythris villari Agenjo, 1971 was described (Agenjo, 1970). In fact, on the advice of H.J. Hanneman, Agenjo initially considered $S$. villari as a subspecies of $S$. clavella; successively, comparing the Spanish material with the Russian male specimens of $S$. clavella from Sarepta (the type locality), the author, observing distinct white markings in the forewing, became convinced that his specimens were not conspecific with clavella and described the new species $S$. villari emphasizing also the differences of the genitalia and VIII sternum. The species identification was confirmed by Passerin d'Entreves (1979) in the revision of Scythridids comparing the holotypus of villari deposited in the collection of Instituto Español de Entomologia in Madrid with the lectotypus of clavella deposited in the collections of British Museum (N. H.) in London. In 1984 comparing unicolor specimens of clavella from France (Hautes Alpes) with the illustrations of the original description of villari, Bengtsson (1984) suggested that villari was a junior synonym of clavella. Additionally, in the same article the author mentioned for the first time the presence in Italy of clavella. In 1991 Derra collected for the first time in Spain some specimens of $S$. clavella on Pyrenees (Bengtsson, 1991). The author refers also to have had a personal communication with Passerin d'Entreves in which the villari-clavella synonymy was criticized based on the constancy of the genitalia features supporting the separation of the two species. After further investigations villari was confirmed to be a distinct species from clavella (Bengtsson, 1997), but clavella was not longer cited for Italy and a unicolorous male specimen collected in Sila Grande, Lorica (1315 msl) in 18-30 June 1986 by Bassi was assigned to villari. Interestingly, investigations on populations of $S$. clavella in the Southern Ural Mountains, where the species is widely distributed and abundant (Nupponen et al., 2000), showed that in all populations in the investigated area specimens 


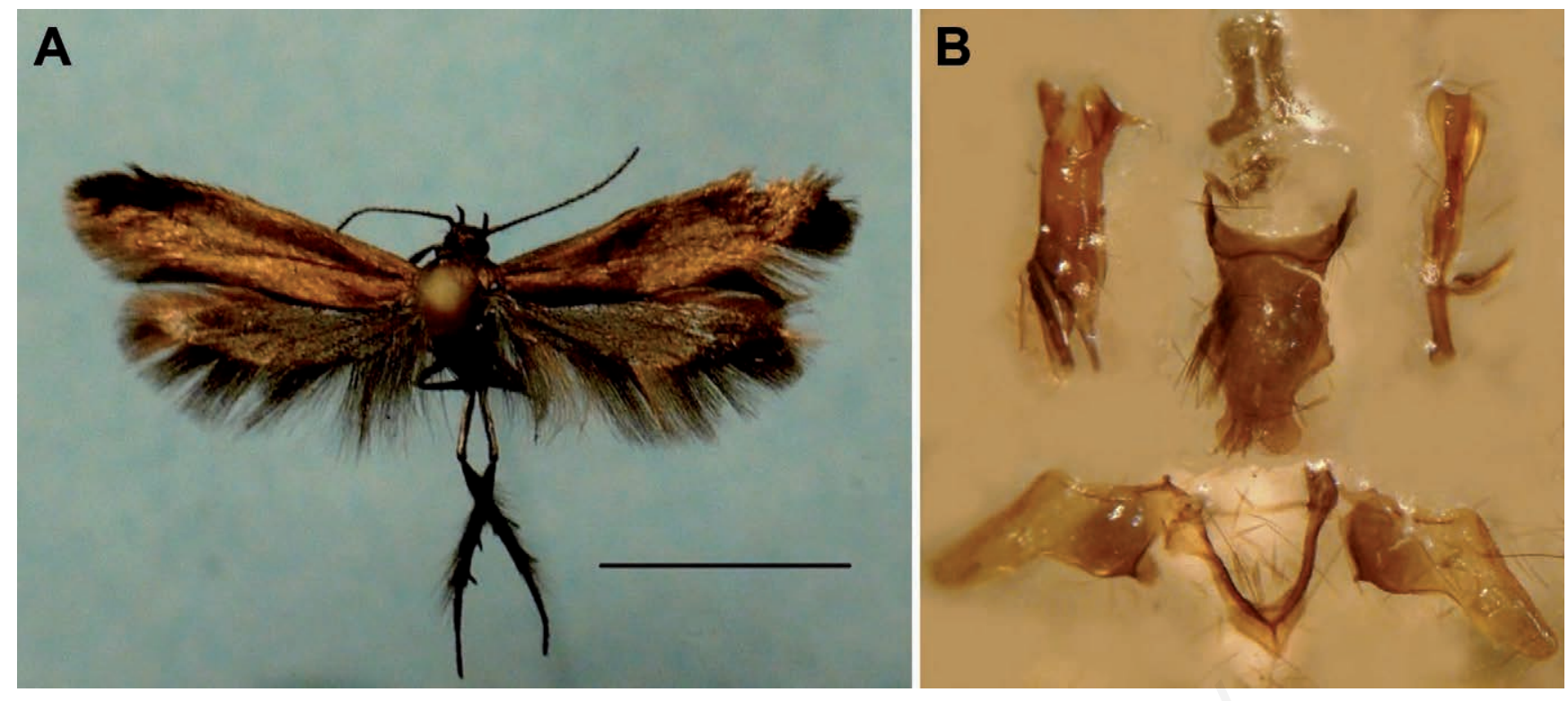

Figure 1. Scythris clavella: male A) adult (bar scale: $5 \mathrm{~mm}$ ) and B) genitalia.

with white marking on forewings (a streak in fold and/or a spot at cell end) were present. The ratio between marked and uni-coloured specimens was estimated in 4 localities (60 specimens each) and varied between 25-30 \% (Nupponen et al., 2000).

\section{Materials and methods}

The collecting site is located in a small area near Vallemare, a secondary village belonging to the municipality of Borbona (Province of Rieti, Latium, Central Italy) (Pinzari et al., 2010, 2013).

In particular, a single male of Scythris clavella was collected by Mario Pinzari on 31.V.2015 at Bivio Brignola (1062 m a.s.l.), Vallemare, Borbona (RI), Italy. The moth was collected by sweeping in a northern facing grassy slope on calcareous soil (1000 $\mathrm{m}$ a.s.l.) in the afternoon. The species was identified by both external habitus and a dissection of the genitalia using the taxonomic characters reported by Bengtsson (1997). The species identification was confirmed by Prof. Pietro Passerin d'Entreves.

Genital parts were mounted on a microscope slide (gen. praep. SCYT 32 , Manuela Pinzari, Figure 1A). The specimen is deposited in the private collection of Mario Pinzari (Rome, Italy).

\section{Discussion}

Supported by Prof. Passerin d'Entreves (personal communication, 2016), I can affirm that the specimen collected in Vallemare and reported here is the first record for Peninsular Italy. The reconstruction of the taxonomic events of the sibling species, $S$. clavella and $S$. villari, and the absence of accurate data of presence of clavella in Italy let me to suppose that the previous citation of clavella for Italy is bound to the improperly proposed synonymy of clavella with villari, this last species well documented to be present in Southern Italy.

The capture of $S$. clavella in Italy is of biogeographic interest, taking into account the distribution of the sibling species $S$. villari. In the Southern Ural Mountains $S$. clavella is present both with unicolor and white marking on forewing (Nupponen et al., 2007), while in Southern and Western Europe and in particular in Spain and in Italy the habitus is exclusively unicolor. Forms of villari with white marking on forewing are not known in literature. These forms mimic bird droppings, as occur in other microlepidoptera (i.e., Olethreutinae), camouflaging and then protecting moths from predators and in particular birds. In the Eastern Europe $S$. clavella is widely distributed, common and sometimes abundant species; this could mean that $S$. clavella is probably well-known to some species of birds that feed on them selecting over time the bird dropping form in these populations. Otherwise the bird dropping form was never recorded in Southern and Western Europe and the limited data available describe $S$. clavella rare, uncommon and never abundant letting suppose that the species could not represent an important trophic resource for local predators and then not be subjected to any selection by predation. Interesting enough that $S$. villari is present only in the south-west of the distribution area of clavella where this species is rare and whenever the distribution areas of the two species overlap villari and clavella show the same habitus.

Beyond the interest of the discovery of $S$. clavella in Peninsular Italy the knowledge on distribution, ecology and biology of this species are still scarce to support the framework proposed and dedicated investigations would be needed.

\section{References}

AGENJO R., 1970 - Descripcion de una nueva especie madrilena del genero Scythris Hb., 1816-1826, dedicada al Excmo. Sr. Prof. Dr. D. Jose Luis Villar Palasi, Ministro de Educacion y Clencia y Presidente del Consejo Superior de Investigaciones Cientificas (Lep. Scythrididae). - EOS Rev. Espanola Entomol. 45: 7-13.

BENGTSSON Å.B., 1997 - Scythrididae. - In: P. HUEMER, O. KARSHOLT \& L. LYNEBORG (Eds.), Microlepidoptera of Europe 2. - Apollo Books, Stenstrup: 301 pp. 
BENGTSSON B.A., 1984 - The Scythrididae (Lepidoptera) of Northern Europe. - Fauna Entomol. Scand. 13: 1-137.

BENGTSSON B.A., 1991 - Contribution to the knowledge of the scythridid fauna of SW Europe (Lepidoptera: Scythrididae). - Shilap Revta. Lepid. 19: 35-51.

KARSHOLT 0., NIEUKERKEN E.J. van, 2013 - Lepidoptera, Moths. Fauna Eur. version 2.6, available from: http://www.fauna-eu.org

NUPPONEN K., BENGTSSON B.A., KAITILA J.P., NUPPONEN T., JUNNILAINEN J., OLSCHWANG V., 2000 - The scythridid fauna of the southern Ural Mountains, with description of fourteen new species (Lepidoptera: Scythrididae). - Entomol. Fennica 11: 5-34.

NUPPONEN K., JUNNILAINEN J., KAITILA J.-P., NUPPONEN T., 2007 Records of scythridid (Lepidoptera: Scythrididae) from the southeastern Balkan. - Entomol. Fennica 18: 1-10.

PASSERIN D'ENTREVES P., 1979 - Revisione degli Scitrididi
(Lepidoptera, Scythrididae) paleartici. IV. I tipi di Scythris dell'Istituto Espanol de Entomologia di Madrid. - Boll. Mus. Zool. Univ. Torino 3: 83-90.

PASSERIN D'ENTREVES P., 1995 - Lepidoptera Gelechioidea, Scythrididae. In: A. MINELLI, S. RUFFO \& S. LA POSTA (Eds.), Checklist delle specie della fauna italiana, 83 - Calderini, Bologna.

PINZARI M., PINZARI M., ZILLI A., 2010 - Deep lepidopterological exploration of Mt Cagno and surroundings (Central Italy), a restricted mountain massif and hotspot for butterfly and moth diversity (Lepidoptera). - Boll. Assoc. Romana Entomol. 65: 3-383.

PINZARI M., PINZARI M., ZILLI A., 2013 - Additions and corrections to the Lepidoptera fauna of Mt Cagno and surrounding (Central Italy), with first records of Caloptilia honoratella and Buvatina stroemella from Italy (Lepidoptera). - Boll. Assoc. Romana Entomol. 68: 1-18. 